\title{
KECERDASAN EMOSIONAL, KOMITMEN ORGANISASI, DAN ORGANIZATIONAL CITIZENSHIP BEHAVIOR TERHADAP KINERJA PEGAWAI BANK PERSERO
}

\author{
HENDRA DARMAWAN \\ YUPITER GULO \\ Trisakti School of Management, Jl. Kyai Tapa No. 20 Jakarta 11440, Indonesia \\ hdarmawan6@yahoo.co.id
}

\begin{abstract}
The purpose of this research is to examine the influence and relationship of performance base on three influence such as emotional intelligent, organizational commitment, and organizational citizenship behavior of PT. Bank Mandiri (Persero) Tbk. Cluster area Bekasi Juanda-1. The methods which is used in the research is descriptive and causality respondents involved in this study as many as 75 people. The study used saturated sampling. The data collection is done by spreading questionnaire. And the method for the data analysis in this research is regression which are multiple linear regression using the Statistical Package for Social Science (SPSS) version 24. The result of this research is, emotional intelligent and organizational citizenship behavior has an impact to performance but organizational commitment have no impact to performance.
\end{abstract}

Keywords: Emotional intelligent, organizational commitment, organizational citizenship behavior, performance

Abstrak: Tujuan penelitian adalah untuk menguji pengaruh dan sifat hubungan antara kinerja dengan tiga pengaruh yaitu kecerdasan emosional, komitmen organisasi dan organizational citizenship behavior di PT. Bank Mandiri (Persero) Tbk. Cluster area Bekasi Juanda-1. Metode yang digunakan dalam penelitian ini adalah deskriptif dan kausalitas responden yang terlibat dalam penelitian ini sebanyak 75 karyawan. Penelitian ini menggunakan teknik sampling jenuh. Pengumpulan data dilakukan dengan cara menyebarkan kuesioner kepada responden. Metode analisis data dalam penelitian ini adalah regresi linier berganda diolah dengan program (SPSS) versi 24. Hasil dari penelitian ini adalah kecerdasan emosional dan organizational citizenship behavior berpengaruh terhadap kinerja namun komitmen organisasi tidak berpengaruh terhadap kinerja

Kata kunci: Kecerdasan emosional, komitmen organisasi, organizational citizenship behavior, kinerja

\section{PENDAHULUAN}

Pada Undang-undang Nomor 10 Tahun 1998 tentang Perbankan, Bank disebutkan sebagai badan usaha yang menghimpun dana dari masyarakat dalam bentuk simpanan dan menyalurkannya kepada masyarakat dalam bentuk kredit untuk meningkatkan taraf hidup masyarakat. Bank umum adalah bank yang melaksanakan kegiatan usaha secara konvensional dan atau berdasarkan prinsip syariah, yang dalam kegiatannya memberikan jasa dalam lalu lintas pembayaran (Hasibuan, 2011). Selain itu Kasmir (2016, 2), menyatakan bank merupakan lembaga keuangan yang kegiatannya menghimpun dana dari masyarakat dalam bentuk simpanan kemudian menyalurkan 
kembali ke masyarakat. Salah satu peranan bank adalah memberikan kredit usaha mikro dimana usaha kecil dan menengah dapat meningkatkan perekonomian Negara.

Usaha mikro, kecil dan menengah (UMKM) merupakan salah satu bagian penting dari perekonomian suatu negara ataupun daerah. Peran penting tersebut telah mendorong banyak negara termasuk Indonesia untuk terus berupaya mengembangkan UMKM. Walaupun kecil dalam skala jumlah pekerja, aset dan omzet, namun karena jumlahnya cukup besar, maka peranan UMKM cukup penting dalam menunjang perekonomian. Oleh karena itu PT. Bank Mandiri senantiasa dalam meningkatkan kinerja nya dalam melakukan pelayanan terhadap nasabah persrorangan maupun koperasi salah satunya dalam pendanaan usaha mikro atau kredit usaha mikro (KUM).

PT. Bank Mandiri (Persero) Tbk. Cluster area Bekasi Juanda-1 merupakan perusahaan yang bergerak di bidang perbankan. Perusahaan ini merupakan kantor cabang pembantu mikro yang terdiri dari 13 kantor cabang pembantu mikro yang tersebar di bekasi kota. Cluster ini dibawahi oleh kantor wilayah MBDC thamrin, Jakarta timur, bertujuan khusus untuk melayani perkreditan dalam skala mikro. Mandiri kredit mikro menyediakan kredit investasi (KI) dan atau kredit modal kerja (KMK) untuk pengembangan usaha produktif maupun konsumtif skala mikro.

Kredit usaha mikro terdiri dari 2 jenis produk kredit. Yang pertama adalah KUM (kredit usaha mikro), kredit usaha mikro khusus diberikan kepada usaha mikro dengan maksimum limit kredit sebesar Rp. 100 Juta. Khusus untuk fasilitas top up diperkenankan sampai dengan limit Rp. 200 Juta. Kedua adalah KSM (kredit serbaguna mikro) Untuk berbagai macam keperluan (serbaguna), selama tidak melanggar kesusilaan, ketertiban umum dan bertentangan dengan hukum dengan maksimum limit kredit sebesar Rp. 50 Juta. (www.bankmandiri.com)

Pertumbuhan kredit PT. Bank Mandiri sepanjang tahun 2016, kredit segmen retail tumbuh 12\%, dari sebesar Rp175,2 triliun menjadi sebesar Rp196,2 triliun yang ditopang oleh pertumbuhan kredit khususnya di segmen Usaha Mikro Kecil dan Menengah. Sampai akhir Desember 2016, penyaluran kredit UMKM Bank Mandiri mengalami peningkatan $6,0 \%$ menjadi sebesar Rp80,3 triliun. Penyaluran kredit UMKM tersebut diberikan kepada 952.248 debitur atau meningkat $12,8 \%$ dibandingkan tahun sebelumnya, yang didominasi oleh sektor Perdagangan dan Pertanian. (www.bankmandiri.com).

Perkembangan dunia bisnis saat ini memberi dorongan bagi perusahaan untuk meningkatkan kinerja mereka, terutama mendorong peningkatan kinerja sumber daya manusia yang telah mereka miliki. Sumber daya manusia merupakan faktor yang penting dalam kesuksesan perusahaan, karena dimulai dari perencanaan hingga tahap evaluasi semua di kelola oleh sumber daya manusia yang berada dalam perusahaan.

Penelitian ini bertujuan untuk menjawab pertanyaan apakah kecerdasan emosional, komitmen organisasi, dan organizational citizenship behavior memberikan pengaruh terhadap kinerja di PT. Bank Mandiri (persero) Cluster area Bekasi Juanda-1. Penelitian ini juga memberikan manfaat bagi perusahaan sebagai bahan masukan kepada perusahaan untuk sebagai bahan evaluasi dan peningkatan kinerja karyawan yang dapat di pengaruhi oleh banyak faktor seperti kecerdasan emosional, komitmen organisasi, dan organizational citizenship behavior.

\section{Kinerja}

Sedarmayanti (2013) menyatakan bahwa kinerja merupakan sistem yang digunakan untuk menilai dan mengetahui apakah seorang karyawan telah melaksanakan 
pekerjaannya secara keseluruhan, atau merup akan perpaduan dari hasil kerja (apa yang harus dicapai seseorang) dan kompetensi (bagaimana seseorang mencapainya).

\section{Kecerdasan Emosional}

Wibowo $(2016,65-66)$ mengemukakan bahwa kecerdasan emosional adalah kumpulan dari kemampuan merasakan dan menyatakan emosi, menerima dalam pemikiran, memahami emosi, dan mengatur emosi dalam diri sendiri dan orang lain.

\section{Komitmen Organisasi}

Robbins (2009, 100) komitmen organisasi didefinisikan sebagai suatu keadaan dimana seorang individu memihak organisasi serta tujuan-tujuan dan keinginannya untuk mempertahankan keanggotaannya dalam organisasi.Karyawan yang berkomitmen merupakan karyawan yang memiliki keinginan kuat untuk bertahan menjadi anggota organisasi (Gulo, 2013).

\section{Organizational Citizenship Behavior} Organizational Citizenship Behavior (OCB), merupakan suatu perilaku sukarela yang tampak dan dapat diamati, dimana didasari oleh suatu motif atau nilai yang dominan juga dapat didasarkan pada reward dan punishment yang bersifat eksternal yang diberikan oleh perusahaan.

Rumusan hoptesis dalam penelitian ini sebagai berikut:

$\mathrm{H}_{1}$ Terdapat pengaruh Kecerdasan Emosional terhadap Kinerja pegawai.

$\mathrm{H}_{2}$ Terdapat pengaruh Komitmen Organisasi terhadap Kinerja pegawai.

$\mathrm{H}_{3}$ : Terdapat pengaruh Organizational Citizenship Behavior terhadap Kinerja pegawai.

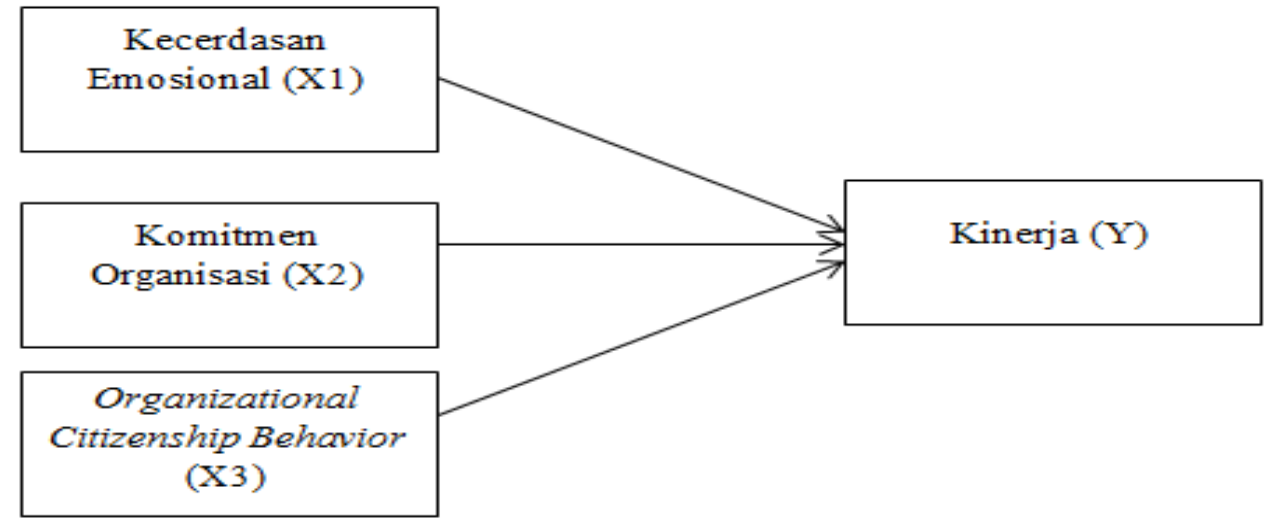

Gambar 1 Model penelitian

\section{METODE PENELITIAN}

Bentuk penelitian yang digunakan dalam penelitian ini adalah penelitian kausalitas. Menurut Sekaran dan Bougie (2013, 98) penelitian kausalitas, yaitu penelitian yang menguji sebab akibat antara variabel independen terhadap variabel dependen. Penelitian ini dilakukan dengan tujuan untuk mengetahui apakah terdapatt pengaruh antara Kecedasan Emosional, Komitmen Organisasi, dan Organizational Citizenship Behavior terhadap Kinerja pegawai di PT. Bank Mandiri (Persero) Tbk. Cluster area Bekasi Juanda-1.

Menurut Sugiyono $(2015,135)$ populasi merupakan wilayah generalisasi yang terdiri atas objek atau subjek yang mempunyai kualitas dan karakteristik yang ditetapkan oleh peneliti 
untuk dipelajari dan kemudian ditarik kesimpulannya. Populasi dalam penelitian ini adalah seluruh staff karyawan PT Bank Mandiri (Persero) Tbk. Cluster area Bekasi Juanda-1 yang telah bekerja minimal 1 tahun berjumlah 75 karyawan, yang terdiri dari staff divisi Mikro kredit analisis, Customer service, Teller, Mikro kredit sales. Sampel adalah bagian dari jumlah dan karakteristik yang dimiliki oleh populasi tersebut (Sugiyono 2015, 136). Sampel pada penelitian ini yaitu, staff karyawan yang bekerja di semua divisi dalam PT Bank Mandiri (Persero) Tbk. Cluster area Bekasi Juanda-1. Jumlah sampel yang digunakan adalah seluruh populasi yaitu sebanyak 75 karyawan. Teknik pengambilan sampel yang digunakan non probability sampling meliputi sampling jenuh merupakan teknik pengambilan sampel dimana semua anggota populasi digunakan sebagai sampel. Hal ini dilakukan karena jumlah populasi relative sedikit. ( sugiyono 2015, 392 )

Pengukuran dalam penelitian ini menggunakan skala Likert. Skala Likert digunakan untuk mengukur sikap, pendapat, dan persepsi seseorang atau sekelompok orang tentang fenomena sosial (Sugiyono 2015, 165). Dalam penelitian ini, pengukurannya diberi tanda Angka 5 = SS (Sangat Setuju), Angka $4=$ S (Setuju), Angka 3 = CS (Cukup Setuju), Angka 2 = KS (Kurang Setuju), Angka $1=$ TS (Tidak Setuju).

\section{HASIL}

Tabel 1 Karakteristik Responden berdasarkan Jenis Kelamin

\begin{tabular}{lllll}
\hline $\begin{array}{l}\text { Jenis Kelamin } \\
\text { Responden }\end{array}$ & Frequency & Percent & $\begin{array}{l}\text { Valid } \\
\text { Percent }\end{array}$ & Cumulative Percent \\
\hline Laki-laki & 39 & 52.0 & 52.0 & 52.0 \\
Wanita & 36 & 48.0 & 48.0 & 100,0 \\
Total & 75 & 100,0 & 100,0 & \\
\hline
\end{tabular}

Sumber: Hasil Kuesioner yang diolah dengan program SPSS.

Tabel 2 Karakteristik Responden berdasarkan Umur

\begin{tabular}{lllll}
\hline $\begin{array}{l}\text { Usia } \\
\text { Responden }\end{array}$ & Frequency & Percent & Valid Percent & $\begin{array}{l}\text { Cumulative } \\
\text { Percent }\end{array}$ \\
\hline $21-30$ & 22 & 29.3 & 29.3 & 29.3 \\
$31-40$ & 37 & 49.3 & 49.3 & 78.7 \\
$41-50$ & 9 & 12.0 & 12.0 & 90.7 \\
$51-60$ & 7 & 9.3 & 9.3 & 100,0 \\
Total & 75 & 100,0 & 100,0 & \\
& & & &
\end{tabular}

Sumber: Hasil Kuesioner yang diolah dengan program SPSS. 
Tabel 3 Karakteristik Responden berdasarkan Pendidikan Terakhir

\begin{tabular}{|c|c|c|c|c|c|}
\hline $\begin{array}{l}\text { Pendidikan } \\
\text { Responden }\end{array}$ & Terakhir & Frequency & Percent & $\begin{array}{l}\text { Valid } \\
\text { Percent }\end{array}$ & $\begin{array}{l}\text { Cumulative } \\
\text { Percent }\end{array}$ \\
\hline Sarjana & & 48 & 64.0 & 64.0 & 64.0 \\
\hline Diploma & & 27 & 36.0 & 36.0 & 100,0 \\
\hline Total & & 75 & 100,0 & 100,0 & \\
\hline
\end{tabular}

Sumber: Hasil Kuesioner yang diolah dengan program SPSS.

Tabel 4 Karakteristik Responden berdasarkan Lama Bekerja

\begin{tabular}{lllll}
\hline $\begin{array}{l}\text { Lama Bekerja } \\
\text { Responden }\end{array}$ & Frequency & Percent & Valid Percent & $\begin{array}{l}\text { Cumulative } \\
\text { Percent }\end{array}$ \\
\hline 1-3 Tahun & 34 & 45.3 & 45.3 & 45.3 \\
4-7 Tahun & 24 & 32.0 & 32.0 & 77.3 \\
8-11 Tahun & 14 & 18.7 & 18.7 & 96.0 \\
12-15 Tahun & 3 & 4.0 & 4.0 & 100,0 \\
Total & 75 & 100,0 & 100,0 & \\
& & & & \\
\hline
\end{tabular}

Sumber: Hasil Kuesioner yang diolah dengan program SPSS.

Tabel 5 Hasil Uji Validitas Kecerdasan Emosional

\begin{tabular}{llll}
\hline $\begin{array}{l}\text { Variabel } \\
\text { Independen }\left(\mathrm{X}_{1}\right)\end{array}$ & $\begin{array}{l}\text { Corrected Item- } \\
\text { Total Correlation }\end{array}$ & $\begin{array}{l}\mathrm{r} \text { table } \\
\mathrm{df}=\mathrm{n}-2\end{array}$ & Keterangan \\
\hline KE_1 & 1 & 0,2272 & Valid \\
KE_2 & 0,302 & 0,2272 & Valid \\
KE_3 & 0,231 & 0,2272 & Valid \\
KE_4 & 0,250 & 0,2272 & Valid \\
KE_5 & 0,270 & 0,2272 & Valid \\
\hline
\end{tabular}

Sumber: Hasil Kuesioner yang diolah dengan program SPSS.

Tabel 6 Hasil Uji Validitas Komitmen Organisasi

\begin{tabular}{llll}
\hline $\begin{array}{l}\text { Variabel } \\
\text { Independen }\left(\mathbf{X}_{2}\right)\end{array}$ & $\begin{array}{l}\text { Corrected Item- } \\
\text { Total Correlation }\end{array}$ & $\begin{array}{l}\mathbf{r} \text { table } \\
\mathbf{d f}=\mathbf{n}-\mathbf{2}\end{array}$ & Keterangan \\
\hline KO_1 & 1 & 0,2272 & Valid \\
KO_2 & 0,354 & 0,2272 & Valid \\
KO_3 & 0,348 & 0,2272 & Valid \\
\hline
\end{tabular}

Sumber: Hasil Kuesioner yang diolah dengan program SPSS. 
Tabel 7 Hasil Uji Validitas Organizational Citizenship Behavior

\begin{tabular}{llll}
\hline $\begin{array}{l}\text { Variabel } \\
\text { Independen }\left(\mathrm{X}_{3}\right)\end{array}$ & $\begin{array}{l}\text { Corrected Item-Total } \\
\text { Correlation }\end{array}$ & $\begin{array}{l}\mathrm{r} \text { table } \\
\mathbf{d f}=\mathbf{n}-2\end{array}$ & Keterangan \\
\hline OCB_1 & 1 & 0,2272 & Valid \\
OCB_2 & 0,355 & 0,2272 & Valid \\
OCB_3 & 0,468 & 0,2272 & Valid \\
OCB_4 & 0,349 & 0,2272 & Valid \\
OCB_5 & 0,427 & 0,2272 & Valid \\
\hline
\end{tabular}

Sumber: Hasil Kuesioner yang diolah dengan program SPSS.

Tabel 8 Hasil Uji Validitas Kinerja

\begin{tabular}{|c|c|c|c|}
\hline $\begin{array}{l}\text { Variabel Dependen } \\
\text { (Y) }\end{array}$ & $\begin{array}{l}\text { Corrected Item- } \\
\text { Total Correlation }\end{array}$ & $\begin{array}{l}r \text { table } \\
\mathrm{df}=\mathrm{n}-2\end{array}$ & Keterangan \\
\hline K_1 & 1 & 0,2272 & Valid \\
\hline K_2 & 0,338 & 0,2272 & Valid \\
\hline K_3 & 0,590 & 0,2272 & Valid \\
\hline K_4 & 0,574 & 0,2272 & Valid \\
\hline K_5 & 0,692 & 0,2272 & Valid \\
\hline K_6 & 0,485 & 0,2272 & Valid \\
\hline
\end{tabular}

Sumber: Hasil Kuesioner yang diolah dengan program SPSS.

Berdasarkan tabel-tabel diatas dapat diketahui bahwa semua indikator dari variabel independen yaitu kecerdasan emosional, komitmen organisasi, dan organizational citizenship behavior serta variabel dependen yaitu kinerja mempunyai $r$ hitung positif dan $r$ hitung > $r$ tabel. Sehingga dapat disimpulkan bahwa semua indikator dalam penelitian ini valid yang artinya setiap instrument dapat digunakan untuk mengukur apa yang seharusnya diukur.

Tabel 9 Hasil Uji Reliabilitas

\begin{tabular}{llll}
\hline Variable & Cronbach Alpha & Alpha & Hasil \\
\hline KE_TOTAL & 0,775 & 0,60 & Reliabel \\
KO_TOTAL & 0,811 & 0,60 & Reliable \\
OCB_TOTAL & 0,781 & 0,60 & Reliable \\
K_TOTAL & 0,784 & 0,60 & Reliable \\
\hline
\end{tabular}

Sumber: Hasil Kuesioner yang diolah dengan program SPSS.

Dari tabel di atas dapat diketahui bahwa semua variabel independen yaitu kecerdasan emosional, komitmen organisasi, dan organizational citizenship behavior serta variabel dependen yaitu kinerja mempunyai nilai Cronbach Alpha $>0,60$ yang artinya butir-butir pernyataan dapat menghasilkan jawaban yang konsisten atau stabil dari waktu ke waktu.

\section{PENUTUP}

Terdapat pengaruh yang signifikan antara kecerdasan emosional terhadap kinerja pegawai di PT. Bank Mandiri (Persero) Tbk. Cluster area Bekasi Juanda-1. Hal ini di tunjukan oleh koefisien korelasi sebesar 0,706 yang artinya kecerdasan emosional $\left(X_{1}\right)$ memiliki hubungan yang kuat dan positif terhadap kinerja 
(Y) dapat dijelaskan oleh variasi kinerja $(Y)$ karena berada diantara 0.60-0.799. Hal ini juga di tunjukan dengan nilai uji t hitung 8,522 dan $\mathrm{p}$ value (sig) sebesar 0.000 yang dibawah alpha $5 \%$.

Terdapat pengaruh yang signifikan antara komitmen organisasi terhadap kinerja pegawai di PT. Bank Mandiri (Persero) Tbk. Cluster area Bekasi Juanda-1. Hal ini juga di tunjukan dengan nilai uji t hitung 1,750 dan $p$ value (sig) sebesar 0.084 yang diatas alpha $5 \%$. Terdapat pengaruh yang signifikan antara Organizational Citizenship Behavior terhadap kinerja pegawai di PT. Bank Mandiri (Persero) Tbk. Cluster area Bekasi Juanda-1. Hal ini juga di tunjukan dengan nilai uji t hitung 5,194 dan $p$-value (sig) sebesar 0.000 yang dibawah alpha $5 \%$.

\section{REFERENCES:}

Gulo, Yupiter. 2013. Faktor-Faktor Yang Mempengaruhi Komitmen Organisasi Karyawan. Jurnal Bisnis dan Akuntansi. 15(1a).

Hasibuan. 2011. Dasar-dasar Perbankan. Jakarta: Bumi Aksara

Kasmir. 2016. Analisis Laporan Keuangan. Jakarta: Raja Grafindo Persada

Sedarmayanti. 2013. Manajemen Sumber Daya Manusia, Reformasi Birokrasi Manajemen Pegawai Negeri Sipil.

Rafika Aditama, Bandung

Sekaran dan Roger Bougie. 2013. Research Methods for Business. United Kingdom: Wiley.

Sugiyono.2015. Metode Penelitian \& pengembangan Research and Development. Bandung: AlfaBeta.

Wibowo. 2016. Perilaku Dalam Organisasi, edisi kedua. Jakarta: PT. Raja Grafindo Persada. 
